\title{
Correlation of Crystal Parameter with Vibrational Data of New Three Tetramethylammonium Salts
}

\author{
S. GHAMMAMY ${ }^{1 *}$, SADJAD SEDAGHAT ${ }^{1}$ and H. SAHEBALZAMANI ${ }^{2}$ \\ ${ }^{1}$ Faculty of Science, Islamic Azad University, Malard Branch, Malard (Iran). \\ ${ }^{2}$ Departments of Chemistry, Faculty of Science, Islamic Azad University, \\ Ardabil Branch, Ardabil (Iran).
}

(Received: February 25, 2012; Accepted: March 25, 2012)

\begin{abstract}
Examination of the solid state infrared spectra of the tetramethylammoniumcation in salts shows correlation of infrared spectral properties with $\mathrm{C}-\mathrm{H} \cdots \mathrm{X}$ hydrogen bonding and crystal habits in these tetramethylammonium salts. The IR predicted crystal habits are comprised by experimental and theoretical data. A good relation between three data has been found. The $\mathrm{C}-\mathrm{H}$ stretching region characteristic hydrogen bonding shifts in the above salts. In this research three complexes of tetramethylammoniumcation have been synthesized and the structures of them have been analyzed by correlation of vibrational data with crystal structures. These correlation shows that crystal symmetry (Tetrahedral), cation distortion (undistorted), site symmetry $\left(D_{2} d\right)$, unite cell symmetry $\left(\mathrm{D}_{4} \mathrm{~h}^{7}\right)$ for $\left(\mathrm{CH}_{3}\right)_{4} \mathrm{NPF}_{6}$ and crystal symmetry (Tetrahedral), cation distortion (distorted), site symmetry $\left(\mathrm{D}_{2} \mathrm{~d}\right)$, unite cell symmetry $\left(\mathrm{D}_{4} \mathrm{~h}^{7}\right)$ for $\left(\mathrm{CH}_{3}\right)_{4} \mathrm{NOH}$ and crystal symmetry (Tetrahedral), cation distortion (undistorted), site symmetry $\left(D_{2} d\right)$, unite cell symmetry $\left(D_{4} h^{7}\right)$ for $\left(\mathrm{CH}_{3}\right)_{4} \mathrm{NF}$.
\end{abstract}

Key words: Crystal parameter, Vibrational data, Tetramethylammonium salts.

\section{INTRODUCTION}

Tetramethylammonium compounds have many applications in science and biology. It is extremely difficult, if not impossible, to prepare single crystals of tetramethylammonium salts suitable for diffraction studies; the available methods of preparation give microcrystalline powders that are not suitable for X-ray single crystal diffraction. Scientists' effort to find and use simple substituted methods for studying crystal habits of tetramethylammonium salts. One of the suggested methods is the use of infrared spectra and assigning of it by symmetry. The vibrational spectrum of the tetramethylammonium $\left(\mathrm{Me}_{4} \mathrm{~N}^{+}\right)$ion has been the subject of several publications during the last four decade ${ }^{1-3}$. Many studies had been done on the vibrational spectra of tetramethylammonium salts and ahowed that it possible to correlate of infrared spectral properties with $\mathrm{C}-\mathrm{H}$...X hydrogen bonding and crystal habit in tetramethylammonium salts such as Harmon et al., ${ }^{4-6}$. On the base of these studies founds that the $\mathrm{C}-\mathrm{H}$ stretching region gives characteristic hydrogen bonding shifts in the tetramethylammonium salts; this effect is particularly intense in the halideand hydroxidecompounds. The $\mathrm{C}-\mathrm{H}$ deformation modes in the $1400-1500 \mathrm{~cm}^{-1}$ region and $\mathrm{N}-\mathrm{C}$ breathing band near $950 \mathrm{~cm}^{-1}$ show perturbations which can be qualitatively used to identify crystal type, and which can be reasonably explained by site symmetry and factor group analysis considerations. Intensity changes in some absorption can be empirically related to steric, size and packing effects. Infrared spectra are correlated with known crystal structures and bond distances for ten of the salts in this paper.

\section{MATERIAL AND METHODS}

All chemicals were of reagent grade quality such as $\left(\mathrm{CH}_{3}\right)_{4} \mathrm{NOH}$ was purchased from Merck company. Tetramethyl ammonium 
fluoride, $\left(\mathrm{CH}_{3}\right)_{4} \mathrm{NFwas}$ synthesized by reported method ${ }^{7}$.

The substrates and the solvents were used after drying and purifying by distillation by usual procedures. The middle fractions were collected after rejecting the head and the tail portions. The IR spectra were recorded on a Shimadzu model 420 spectrophotometer. The UV/ Visible measurements were made on a Shimadzu model 2100 spectrometer. Proton, ${ }^{13} \mathrm{C},{ }^{19} \mathrm{~F}$ NMR were carried out on a Bruker AVANCE DRX 500 spectrometer at $500,125,470.66 \mathrm{MHz}$. All the chemical shifts are quoted in ppm using the highfrequency positive convention; ${ }^{1} \mathrm{H}$ and ${ }^{13} \mathrm{C}$ NMR spectra were referenced to external $\mathrm{SiMe}_{4}$ and ${ }^{19} \mathrm{~F}$ NMR spectra to external $\mathrm{CFCl}_{3}$. This salt was estimated iodometrically after oxidizing the compound with acidic persulphate solution. Fluoride content was determined gravimetrically as $\mathrm{PbClF}^{8-9}$. The percentage compositions of carbon, hydrogen and nitrogen were obtained from the microanalytical Laboratories, Department of Chemistry, OIRC, Tehran.

\section{Synthesis of tetramethylammonium compounds}

$\left(\mathrm{CH}_{3}\right)_{4} \mathrm{NPF}_{6}$ was prepared inside a glove box purged with argon. $\mathrm{PF}_{5}$ was dissolved in dry acetonitrile $(25 \mathrm{ml})$ in a polyethylene beaker and a stoichiometric amount of tetramethylammoniumfluoride was added with stirring at room temperature. Within 5 minutes a solution formed which upon refrigerating, gave solid $\left(\mathrm{CH}_{3}\right)_{4} \mathrm{NPF}_{6}$, which was isolated by filtration. The solid was washed with dry isopropanol and diethyl ether, and dried under vacuum for 1 hour. UV/Visible, ${ }^{19} \mathrm{~F}-\mathrm{NMR}$, ${ }^{13} \mathrm{C}-\mathrm{NMR}$ and ${ }^{1} \mathrm{H}$-NMR were used for characterization of these compoundsformula.

For $\left(\mathrm{CH}_{3}\right)_{4} \mathrm{NPF}_{6}$ green microcrystalline was obtained. The compound was finally dried in vacuum over phosphorous penfluoride. The yield of $\left(\mathrm{CH}_{3}\right)_{4} \mathrm{~N}\left[\mathrm{MoCl}_{5} \mathrm{~F}\right]$ was ca $98 \%$. Satisfactory elemental analysis was obtained.For $\left(\mathrm{CH}_{3}\right)_{4} \mathrm{NPF}_{6}$, IR data and spectrum for cation and anions have been assigned to different modes, respectively. (Fig.1, Table 1)

For $\left(\mathrm{CH}_{3}\right)_{4} \mathrm{NOH}$,IRdata and spectrum for cation and anion have been assigned to different modes, respectively.(Fig. 2, Table 2)
For $\left(\mathrm{CH}_{3}\right)_{4} \mathrm{NF}, \mathrm{IR}$ data and spectrum for cation and anion have been assigned to different modes, respectively.(Fig. 3, Table 3)

\section{Structure solution and refinement}

The structure of crystallized compounds have been solved by direct methods and refined by full-matrix-least squares techniques on $\mathrm{F}^{2}$. All non-hydrogen atoms were refined anisotropically. The position of hydrogen atom was assigned an isotropic thermal parameter. Corrections for the LP as well as the empirical correction for absorption using the SADABS programs were applied. All structural calculations were carried out by using the SHELXTL V. 5.10 structure determination software. The intensity data were collected on a SIMENS SMART CCD diffractometer with graphitemonochromated Mo Ká radiation. The crystal structure was solved by directed methods ${ }^{9}$.

\section{RESULTS AND DISCUSSION}

The crystal and molecular structure of tetramethylammoniumcompounds, have been determined at 130 (2) $\mathrm{K}$ by X-ray diffraction. X-ray data clearly demonstrate inequality between different bonds that is responsible for the higher reactivity of these compounds over similar agents in terms of the amount of solvent required, short reaction times and high yields. The reason for this inequality is due to the $\mathrm{CH}$...N hydrogen bond that forms between the methyl hydrogen of the cation and hydroxide or halide atoms of the anion ${ }^{10}$. This type of hydrogen bonding in tetramethylammonium salts has been studied by Harmon et al.The IR spectrum and hydrogen bonding of these compounds is similar to the other tetramethylammoniumsalts that show the existence of hydrogen bonding.

Halo complexes of transition metals are also as general purpose, stoichiometric oxidant in synthetic organic chemistry,and a variety of reaction pathways including both atom-transfer and electron-transfer are involved ${ }^{12}$.

The results of chemical analyses of the $\left(\mathrm{CH}_{3}\right)_{4} \mathrm{NPF}_{6}$ green product revealed the occurrence of $\mathrm{C}: \mathrm{H}: \mathrm{N}$ in the atomic ratio, while that of chemical determination of the different state of 
phosphorous by iodometry conspicuously showed the presence of phosphorous. It may be emphasized that the chemical estimation of oxidation state of a metal, capable of displaying variable oxidation numbers, is particularly important and crucial in assessing its actual oxidation state in a specific compound ${ }^{11}$.

Also magnetic susceptibility measurements show that $\left(\mathrm{CH}_{3}\right)_{4} \mathrm{NPF}_{6}$ has two odd electrons. Magnetic moment is 2.91BM that to confirm to amount mentioned in sources for phosphorous compound and $\mathrm{d}^{2}$ electronic configuration of central metal.

The IR spectra of the $\left(\mathrm{CH}_{3}\right)_{4} \mathrm{NPF}_{6}$ recorded both in $\mathrm{KBr}$ and in nujol media showed the characteristics of tetramethylammonium $\left(\mathrm{CH}_{3}\right)_{4} \mathrm{~N}^{+}$ ion, and this part of the spectrum is similar to that observed for $\left(\mathrm{CH}_{3}\right)_{4} \mathrm{~N}^{+}$in the case of

Table 1: The frequencies $\left(\mathrm{cm}^{-1}\right)$ and assignment of cation and anion of $\left(\mathrm{CH}_{3}\right)_{4} \mathrm{NPF}_{6}$

\begin{tabular}{|c|c|c|c|c|c|}
\hline$v, \mathbf{c m}^{-1}$ & Assignment & Intensity & $v, \mathbf{c m}^{-1}$ & Assignment & Intensity \\
\hline & \multirow[t]{5}{*}{$\left(\mathrm{CH}_{3}\right) 4 \mathrm{~N}^{+}$} & \multirow[t]{5}{*}{$(w)$} & 1470 & $v 15$ & (s) \\
\hline & & & 1400 & $v 15$ & (m) \\
\hline & & & 1279 & vrock & (w) \\
\hline & & & 470 & $v 19$ & (m) \\
\hline & & & 446 & $v 19$ & (m) \\
\hline 3430 & $v \mathrm{CH}_{3}+1 / 219$ & $(w)$ & & & \\
\hline 3370 & $v \mathrm{CH}_{3}+1 / 28$ & (m) & & & \\
\hline 3102 & $v \mathrm{CH}_{3}$, asym. Str. & (s) & & & \\
\hline 3015 & $v 13, v \mathrm{CH}_{3}$, asym. Str & $(w)$ & & & \\
\hline 2990 & v14, $v \mathrm{CH}_{3}$, asym. Str. & (s) & & $\mathrm{PF}_{6}^{-}$ & \\
\hline 2772 & $v 14, \mathrm{vCH}_{3}$, asym. Str & $(w)$ & & & \\
\hline 2640 & $v 7+v 16$ & $(w)$ & 935 & vasP-F & (s) \\
\hline 2470 & $v 3+v 8+v 16$ & $(w)$ & 904 & vsP-F & (s) \\
\hline 1838 & $v 8+v 15$ & & 636 & $v P-F$ & (s) \\
\hline
\end{tabular}

Table 2: The frequencies $\left(\mathrm{cm}^{-1}\right)$ and assignment of cation and anion of $\left(\mathrm{CH}_{3}\right)_{4} \mathrm{NOH}$

\begin{tabular}{|c|c|c|c|c|c|}
\hline$v, \mathbf{c m}^{-1}$ & Assignment & Intensity & $v, \mathbf{c m}^{-1}$ & Assignment & Intensity \\
\hline & $\left(\mathrm{CH}_{3}\right) 4 \mathrm{~N}^{+}$ & & 1470 & $v 15$ & (s) \\
\hline & & & 1400 & $v 15$ & (m) \\
\hline & & & 1279 & vrock & $(w)$ \\
\hline & & & 470 & $v 19$ & (m) \\
\hline & & & 446 & $v 19$ & (m) \\
\hline 3430 & $v \mathrm{CH}_{3}+v 19$ & $(w)$ & & & \\
\hline 3370 & $v \mathrm{CH}_{3}^{3}+v 8$ & (m) & & & \\
\hline 3102 & $v \mathrm{CH}_{3}$, asym. Str. & (s) & & & \\
\hline 3015 & $v 13, v \mathrm{CH}_{3}$, asym. Str & $(w)$ & & & \\
\hline 2990 & $v 14, v \mathrm{CH}_{3}$, asym. Str. & (s) & & & \\
\hline 2772 & $v 14, v \mathrm{CH}_{3}$, asym. Str & $(w)$ & & & \\
\hline 2640 & $v 7+v 16$ & $(w)$ & & & \\
\hline 2470 & $v 3+v 8+v 16$ & $(w)$ & & & \\
\hline 1838 & $v 8+v 15$ & $(w)$ & & & \\
\hline
\end{tabular}


tetramethylammoniumsalt. The additional bands have been appeared and have been assigned respectively [11]. Which owe their origins to the presence of coordintatedphosphorous and fluoride group at $\mathrm{PF}_{6}$ ion. Table 1 shows the assignment of $\left(\mathrm{CH}_{3}\right)_{4} \mathrm{NPF}_{6} \mathrm{IR}$ spectrum. Thus considering the results of elemental analyses, chemically estimated oxidation state phosphorous, electrochemical analyses and IR spectral studies it may be safely inferred that the brown reduced product is $\left(\mathrm{CH}_{3}\right)_{4} \mathrm{NPF}_{6}$ with the metal occurring as phosphorous.

This again lends support to our notion that the phosphorous of $\left(\mathrm{CH}_{3}\right)_{4} \mathrm{NPF}_{6}$ is reduced to a Molibden species in the oxidations of organic substrates studied herein. Calculation of structure of $\mathrm{PF}_{6}-$ by DFT method shows the declined trigonal structure.

\section{Similar results have been found for $\left(\mathrm{CH}_{3}\right)_{4} \mathrm{NOHand}\left(\mathrm{CH}_{3}\right)_{4} \mathrm{NFcompound}$.}

Infrared and Raman spectra of tetrahedral $\mathrm{M}\left(\mathrm{CH}_{3}\right)_{4}$ molecules have been discussed in considerable details. It is commonly assumed that tetramethylammonium ion on the average has $T_{d}$ symmetry, and an approximate tetrahedral $\mathrm{C}_{4} \mathrm{~N}$ skeleton has been established for many $\left(\mathrm{CH}_{3}\right)_{4} \mathrm{~N}^{+}$salts by means of $\mathrm{X}$-ray crystallography. In this approximation, the 45 degrees of vibrational freedom of the ion are distributed on the symmetry species of point in this way by: $\tilde{\mathrm{A}}_{\mathrm{vib}}=3 \mathrm{~A}_{1}+1 \mathrm{~A}_{2}+4 \mathrm{E}+4 \mathrm{~T}_{1}+7 \mathrm{~T}_{2}$. The $\mathrm{Me}_{4} \mathrm{~N}^{+}$ ion has 19 normal vibrations which belong to the following irreducible representations of its symmetry group $T_{d}: 3 A_{1}+A_{2}+4 E+4 T_{1}$. From group theoretical it follows that of all these vibrations only those with $\mathrm{T}_{2}$ symmetry are infrared active, whereas in isotropic Raman scattering only the $A_{1}$ modes and in anisotropic scattering only the $E$ and $T_{2}$ modes are allowed. Species of this type have seven infrared active $T_{2}$ bonds under $T_{d}$ symmetry, but formation of hydrogen bonding between tetramethylammonium and suitable anions can distort $T_{d}$ symmetry of this cation. At this state the infrared spectrum may be modified through the appearance of previously forbidden bands or the splitting of bands can arise from the coupling of the vibrations of molecules in the same unit cell. By examination of the solid state infrared spectrum of tetramethylammonium ion salt it is possible to predict the lattice, the approximate size of the anion, the closeness of approach of the cation to each other, the presence or absence of cation to anion hydrogen bonding and whether or not the cation is distorted from tetrahedral. The detail assignment of IR spectrum of tetramethyl ammonium compounds, show (Fig. 1, 2, 3). The IR

Table 3: The frequencies $\left(\mathrm{cm}^{-1}\right)$ and assignment of cation and anion of $\left(\mathrm{CH}_{3}\right)_{4} \mathrm{NF}$

\begin{tabular}{|c|c|c|c|c|c|}
\hline$v, \mathbf{c m}^{-1}$ & Assignment & Intensity & $v, \mathrm{~cm}^{-1}$ & Assignment & Intensity \\
\hline & $\left(\mathrm{CH}_{3}\right) 4 \mathrm{~N}^{+}$ & & 1470 & $v 15$ & (s) \\
\hline & & & 1400 & $v 15$ & (m) \\
\hline & & & 1279 & vrock & (w) \\
\hline & & & 470 & $v 19$ & (m) \\
\hline & & & 446 & $v 19$ & (m) \\
\hline 3430 & $v \mathrm{CH}_{3}+v 19$ & (w) & & & \\
\hline 3370 & $v \mathrm{CH}_{3}+\mathrm{v} 8$ & (m) & & & \\
\hline 3102 & $v \mathrm{CH}_{3}$, asym. Str. & (s) & & & \\
\hline 3015 & $v 13, v \mathrm{CH}_{3}$, asym. Str & (w) & & & \\
\hline 2990 & $v 14, v \mathrm{CH}_{3}$, asym. Str. & (s) & & & \\
\hline 2772 & $v 14, v \mathrm{CH}_{3}$, asym. Str & (w) & & & \\
\hline 2640 & $v 7+v 16$ & (w) & & & \\
\hline 2470 & $v 3+v 8+v 16$ & (w) & & & \\
\hline 1838 & $v 8+v 15$ & (w) & & & \\
\hline
\end{tabular}




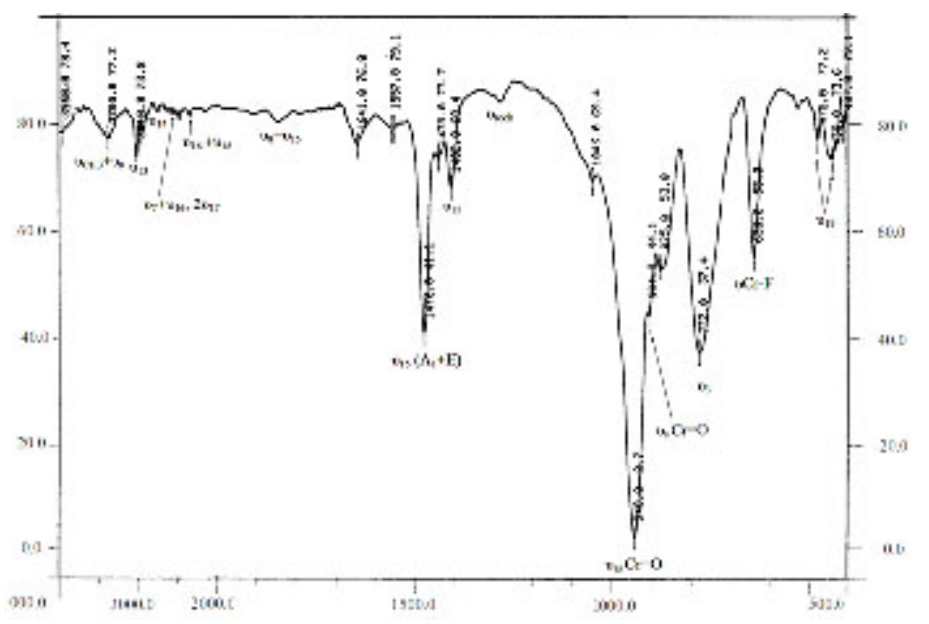

Fig. 1: The IR spectrum regions of the $\left(\mathrm{CH}_{3}\right)_{4} \mathrm{NPF}_{6}$

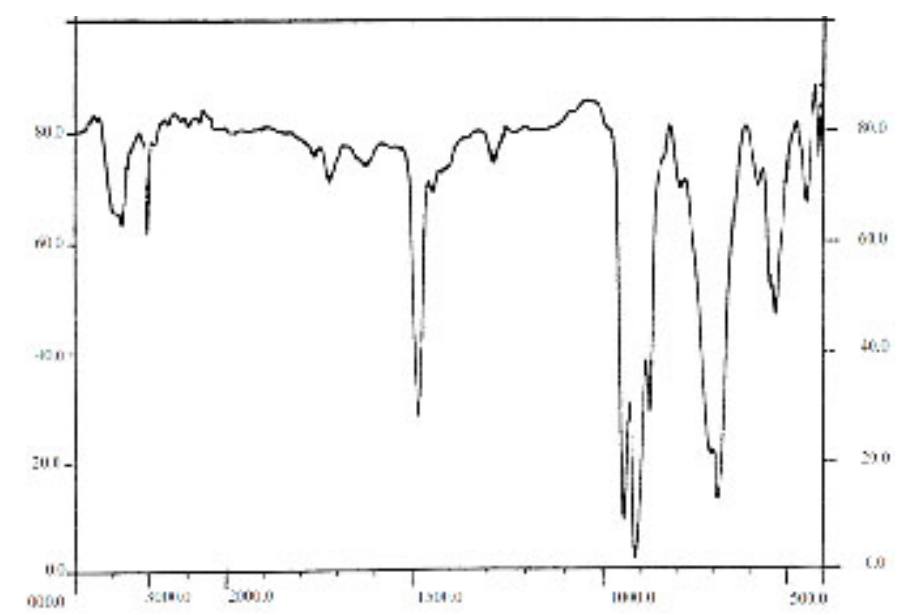

Fig. 2:The IR spectrum regions of the $\left(\mathrm{CH}_{3}\right)_{4} \mathrm{NOH}$

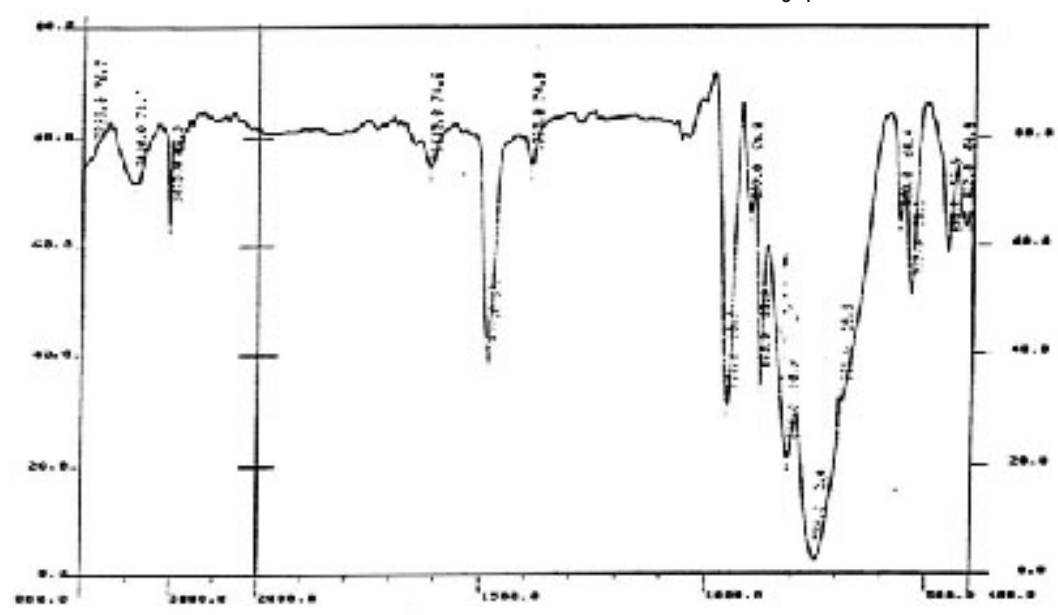

Fig. 3: The IR spectrum regions of the $\left(\mathrm{CH}_{3}\right)_{4} \mathrm{NF}$ 


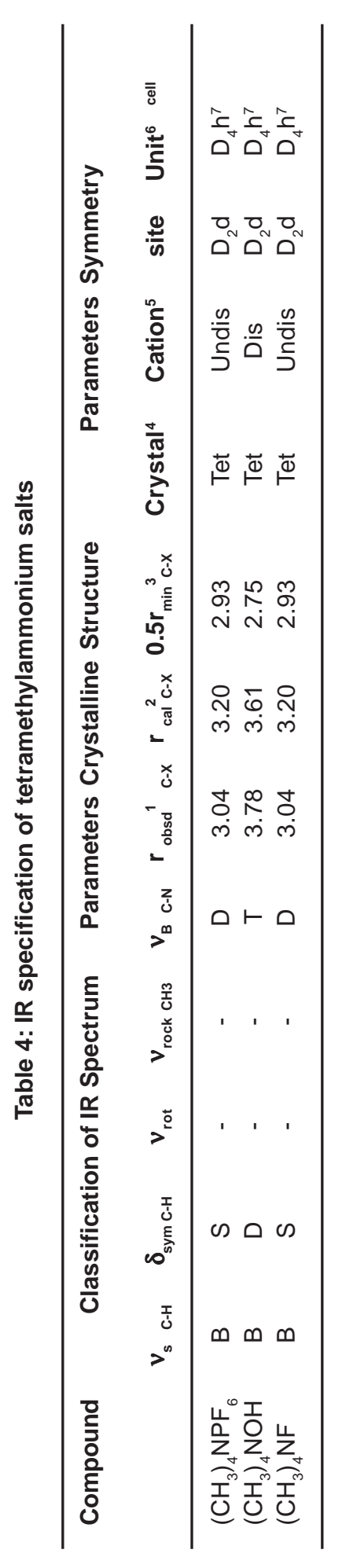

specification of $\left(\mathrm{CH}_{3}\right)_{4} \mathrm{NPF}_{6}$, and symmetry correlations shows that this compound is crystallized such as $\left(\mathrm{CH}_{3}\right)_{4} \mathrm{NClO}_{4}$ and must have the same crystal habits and parameters.

The IR spectrum of the $\left(\mathrm{CH}_{3}\right)_{4} \mathrm{NOHand}$ symmetry correlations shows that this compound is crystallized such as $\left(\mathrm{CH}_{3}\right)_{4} \mathrm{NCl}$ and must have the same crystal habits and parameters. The IR spectrum of the $\left(\mathrm{CH}_{3}\right)_{4} \mathrm{NFand}$ symmetry correlations shows that this compound is crystallized such as $\left(\mathrm{CH}_{3}\right)_{4} \mathrm{NClO}_{4}$ and must have the same crystal habits and parameters. The assignments of the IR spectra in tables 1,2, 3 refer to the cation and anion spectra. The specification of the tetramethylammonium compounds, on the base of IR spectra splitting and Harmon regions shows Table 3.As told, if the infrared spectra of the tetramethylammonium ions in crystalline salts correlated with known crystal structures, it might be possible to predict the crystal habit of salts where diffraction data are not available.

\section{CONCLUSSIONS}

We published these three complexes separately, but now we compare their spectroscopic data especially electronic transitions. As seen the number and shapes of transitions completely different with three similar ions. The salts of $\left[\left(\mathrm{CH}_{3}\right)_{4} \mathrm{~N}\right]$ were synthesized in one step and characterized by elemental analysis, IR, UV/Visible, and ${ }^{81} F-N M R$ techniques. Production of these compounds show the ability of salts in bromide addition to transition metal and main group elements compounds. The optimized structures are in good agreement with the available experimental results. These correlation shows that crystal symmetry (Tetrahedral), cation distortion (undistorted), site symmetry $\left(D_{2} d\right)$, unite cell symmetry $\left(D_{4} h^{7}\right)$ for $\left(\mathrm{CH}_{3}\right)_{4} \mathrm{NPF}_{6}$ and crystal symmetry (Tetrahedral), cation distortion (distorted), site symmetry $\left(\mathrm{D}_{2} \mathrm{~d}\right)$, unite cell symmetry $\left(\mathrm{D}_{4} \mathrm{~h}^{7}\right)$ for $\left(\mathrm{CH}_{3}\right)_{4} \mathrm{NOH}$ and crystal symmetry (Tetrahedral), cation distortion (undistorted), site symmetry $\left(\mathrm{D}_{2} \mathrm{~d}\right)$, unite cell symmetry $\left(\mathrm{D}_{4} \mathrm{~h}^{7}\right)$ for $\left(\mathrm{CH}_{3}\right)_{4} \mathrm{NF}$.

\section{ACKNOWLEDGMENTS}

The authors wish to express their sincere thanks to Dr.Gh. RezaeiBehbahani and Islamic Azad University, for their assistance. 


\section{REFERENCES}

1. Crosthwaite J. M., Muldoon M. J., Dixon J. K.,Anderson J. L. andBrennecke J. F., J. Chem. Thermodyn., 37: 559 (2005)

2. Ghammamy S. and Dastpeyman S. Transition Metal Chemistry, 31: 482 (2006).

3. A. Wahab, Orient. J. Chem., 27(3): 1199-1202 (2011).

4. Harmon K. M., Gennick I. and Madeira S. L.J. Phys. Chem.,78: 1845 (1974).

5. Mahjoub A. R., Ghammami S. and Kassaee M. Z. Tetrahedron Lett.,44: 4557 (2003).

6. Granier W., Vilminot S., Vidal J. D. and Cot L.J. Fluor. Chem., 19: 123 (1981).

7. Antharjanam P. K. S., Jaseer M., Ragi K. N. and Prasad E., J. Photochem. Photobiol. A: Chem., 203: 50 (2009).
8. Christe K. O., Wilson W. W., Wilson R. D., Bau R. and Feng J., J. Am. Chem. Soc., 112: 7619 (1990).

9. Zhao D. Z., Fei R. and Scopelliti P., J. Inorg.Chem., 43: 2197 (2004).

10. Mahjoub A. R., Ghammami S., Abbasi A. R., Hossainian A J. Chem. Res., 200: 48 (2000).

11. Ghammamy S. and RahnamaBaghy M.Russ. J. Inorg. Chem., 32:456 (2007).

12. Anouti M., Caillon-Caravanier M., Dridi Y., Jacquemin J., Hardacre C. and Lemordant D., J. Chem. Thermodyn., 41: 799 (2009).

13. Ghammamy S., Wing-Tak W., Rahnamabaghy M., Mehrani K., Afrand H. and DastpeymanS.J. Coord. Chem., 61: 3225 (2008). 